\title{
POPULIST BECOMING: The Red Shirt Movement and Political Affliction in Thailand
}

\author{
BO KYEONG SEO \\ Yonsei University \\ (iD) https:/ / orcid.org/0000-0002-7481-3296
}

In contemporary narratives of political crises, skepticism of populism is nothing new. For many media and academic commentators, populism represents a contamination of liberal democracy by dangerous demagogy, cheap emotionalism, and mass manipulation. When the populism of today is broadly recognized as such, populist is less likely to be used as a self-descriptive identity; rather, it becomes a designation applied by nonparticipants. As Jean Comaroff $(2011,100)$ aptly points out, it works as a shifter, a tool of indexing, in the sense that the term populist is "more about marking difference than denoting content, and its meaning being largely relative to the standpoint from which it is deployed." In this article, I explore how the space opened up by the workings of this political indexing provides fertile ground for the process of becoming subjects. While critics apply the label of populism pejoratively to political leaders who claim to speak for "the people," how do the people who are allegedly spoken for experience populist moments themselves? How does one become a populist subject? How can we perceive the demos in the process of becoming?

This article makes the case for ethnographically grounded studies of populist mobilization by focusing on a mass movement known as the Red Shirts in Thailand. The birth of this movement is usually traced back to the emergent popular 
politics represented by Thaksin Shinawatra. Since Thaksin's election as the country's premier in 2001 based on strong support from informal and rural masses, parties associated with him have won every election. Soon after his 2005 election victory, opposition movements against his ascendency had also taken shape, mainly among Bangkok-based upper middle-class and royalist elites. Clashes between proand anti-Thaksin groups boiled over when Thaksin was ousted in a military coup in September 2006. From then and until the 2014 coup that removed Thaksin's sister Yingluck Shinawatra from office, political polarization became a key feature of Thai politics. It was shaped as the color-coded politics between the Yellow Shirts, who identified Thaksin as a serious threat to the traditional royalist establishment and paved the way for toppling the elected government, and the Red Shirts, who continued to support Thaksin-associated parties and opposed the military's seizure of power. ${ }^{1}$ The military junta that seized power in 2014 swiftly suppressed the divisive tumult, immensely strengthening the country's authoritarian political arrangements. General elections were eventually held in March 2019, but the results remained clouded by irregularities and mistrust. ${ }^{2}$ Far from ending fifteen years of political turmoil, the 2019 election has set a new stage for further conflict and struggles.

In this prolonged political chaos, the tainted meanings associated with the word populism have played a significant role in Thai society. Since Thaksin's governance was deemed "Thaksin-style populism [Thaksina prachaniyom]," commentators have paid much attention to his style of leadership as a driving force behind the rise of populism in Thailand. ${ }^{3}$ Within this formulation of personalism, supporters of Thaksin and the Red Shirts automatically take the position of his clients. ${ }^{4}$ AntiThaksin and royalist groups aligned with the Yellow Shirts viewed their struggle as a battle between "moral royalists opposed to corrupt, elected politicians" (Kanchoochat and Hewison 2016, 374), describing Thaksin and his associates as populist demagogues carrying the seed of disaster. This interpretative frame effectively dismissed Thaksin's popularity — confirmed by elections - as the outcome of mass clientelism, thus undermining the legitimacy of the majority of the electorate and justifying military interventions. ${ }^{5}$ The key political effect of so-called Thaksin-style populism does not just concern content; it also has moral connotations that serve to disparage the significance of the emerging social and political demands.

My choice to describe the Red Shirts as populists, although most of those who participate in the movement would not label themselves as such, owes to the discursive and political stakes under which this morally imbued concept of populism operates. In this article, I reject the assumption that populism constitutes 
a deviation from politics-as-usual and instead use the term in a descriptive sense. This approach takes as its point of departure Ernesto Laclau's (2005) conception of populism as a political logic. He defines populism as a form of political discourse that establishes the political frontier between two competing, antagonistic groups (us/them, underdog/oligarchy, the people/the system). "The people," in Laclau's formulation, is not a preexisting group that shares common interests or socioeconomic conditions, but rather emerges as the subject of collective action, brought into existence through the processes of interpellation, performance, and articulation. Other critical theorists have also taken populism as a crucial dimension of political life and refused the supposition that simply equates it with clientelism and patronage (Canovan 1982; Rancière 2006; Mouffe 2018). As populism expresses diverse or even contrasting images of "the people," it "must be conceived as a possibility embedded in the very practice of democracy" (Arditi 2004, 141).

Following this line of thought, I propose a different way of understanding Thailand's political polarization, arguing that it does not represent the simple outcome of the clash between populist and anti-populist blocs or democratic and anti-democratic blocs for power. Instead, I believe it reflects the paradoxical relationship of populism to democracy. Summing up Thailand's color-coded politics as "the struggle between the rulers and the ruled," the historical anthropologist Tyrell Haberkorn $(2018,190)$ differentiates "the royalist-nationalist yellow shirts, who favored rule by a moral few" from "the populist-democratic red shirts, . . who ... . wanted rule by those chosen by the majority." Although it is necessary to differentiate the two camps' distinct ideological positions, especially regarding the norms of electoral democracy, this categorization fails to denote both groups' common ground: the will of "the people." Given that the Yellow Shirts consistently mobilized the people's common will against "corrupt" elections or for protecting the monarchy, it might also qualify as a populist movement. ${ }^{6}$ Robert Samet's (2013, 529) work on the political antagonism between supporters and opponents of the former Venezuela President Hugo Chávez proves particularly useful to grasp how two oppositional camps can both adhere to the shared logic of populism, as they both tend to define themselves as "victims who mobilize the force of popular sovereignty against the abuse of power."

Taking the term populist-democratic - the description Haberkorn gives of the Red Shirts — as a springboard for further analysis, I want to shift attention to the nature of the hyphen that links and separates nation and state, citizen and subject, and populism and democracy. By perceiving the nation-state as a key problematic of state power, Begoña Aretxaga $(2003,397)$ suggested that the hyphen does not 
indicate a self-evident connection between two distinctive entities, but bears "a variety of relations that are ambivalent, ambiguous, hostile, violent, porous.” Being enmeshed in the Red Shirt movement, as I show below, entails being enmeshed in an undetermined set of relations between populism and democracy. I develop the concept of populist becoming to discern how political subjectivities are not just determined by, but also constituted within populist orders. Populist becoming not only includes "individual and collective struggles to come to terms with events and intolerable situations and to shake loose" (Biehl and Locke 2017, 42) but also possibilities to undo and redo populism by drawing on such experiences of struggle. The articulation of populist subjects' aspirations and afflictions provides a window into the unfinished aspects of political mobilization from the realm of the ordinary.

In the context of the global rise of populism (Moffitt 2016; Bessire and Bond 2017), when one's participation in and demands for social transformation are identified as both democratic struggle and the regressive politics of the crowd, how can the political potential of this ambiguous subject position be clarified? Media scholars Paula Chakravartty and Srirupa Roy $(2017,4075)$ note that in recent analyses of global populism, "the angry, misinformed, and deluded voter" still emerges as the main figure, because the presentist approach that overvalues the immediate outcome of an election fails to grasp "the antecedents, afterlives, and grounds of the populist everyday" (Chakravartty and Roy 2017, 4077). In moving beyond this ahistorical conception of a populist voter, I seek to understand political "history in person" (Holland and Lave 2001) and show how it entails the development and transformation of populist subjectivities.

At the heart of this article lies the biography of a woman in her sixties whom I call Ta. ${ }^{7}$ I first met her in July 2012 while conducting fieldwork on universal health coverage in Chiang Mai. Ta was one of the active Red Shirt supporters with whom I happened to develop close social ties at that time. Although the country's political polarization was not my main research topic then, I could not detach myself from it. The establishment of universal health coverage was one of the major elements of Thaksin's electoral platform, and the city, also Thaksin's hometown, harbored various groups related to the Red Shirts. I returned to Chiang Mai in 2014 and again in 2016 and continued to visit and accompany Ta. This article draws on fieldwork materials from this period. Although Ta's changing political position resonates deeply with the rise, peak, and suppression of the Red Shirt movement, I do not aim to present her as a stereotypical participant of the movement and to draw sociopolitical conclusions about the general implications of pop- 
ulism in Thailand. Here, instead of assuming Ta as a part to be aggregated into bigger units of a social class or regional community, I attend to her singularity as a person shaping her own political life. It is an attempt to write a microhistory through the eyes of "those who live the discrepancy between rhetoric and reality, political ideals and lived actualities" (Comaroff 2011, 101).

\section{THE RED CROWD}

In July 2012, I was told by several Red Shirt women not to miss an annual merit-making ceremony for Thaksin. When I arrived in one of the well-known Red Shirt gathering places located in the old center of the city, around thirty women were already there waiting for the monks. It was still early, but Ta, a lottery-ticket seller and the mother of seven children, was busy setting up her food stand. Other women showed me the spacious reception hall temporarily set aside for the day's events. It was full of a hundred ton kathin, tree-shaped sticks adorned with golden and silver papers, crisp 100-baht banknotes, and red dots printed with Thaksin's picture. An old woman, wearing a red T-shirt that also featured Thaksin's smiling face, explained to me that the day before today's "party," hundreds of people all around Chiang Mai had marched together and carried these money trees to the present venue for merit-making. At almost 11 a.m., the monks arrived, and those assembled, mostly women in middle to old age, all sat in the hall. A lay ritual

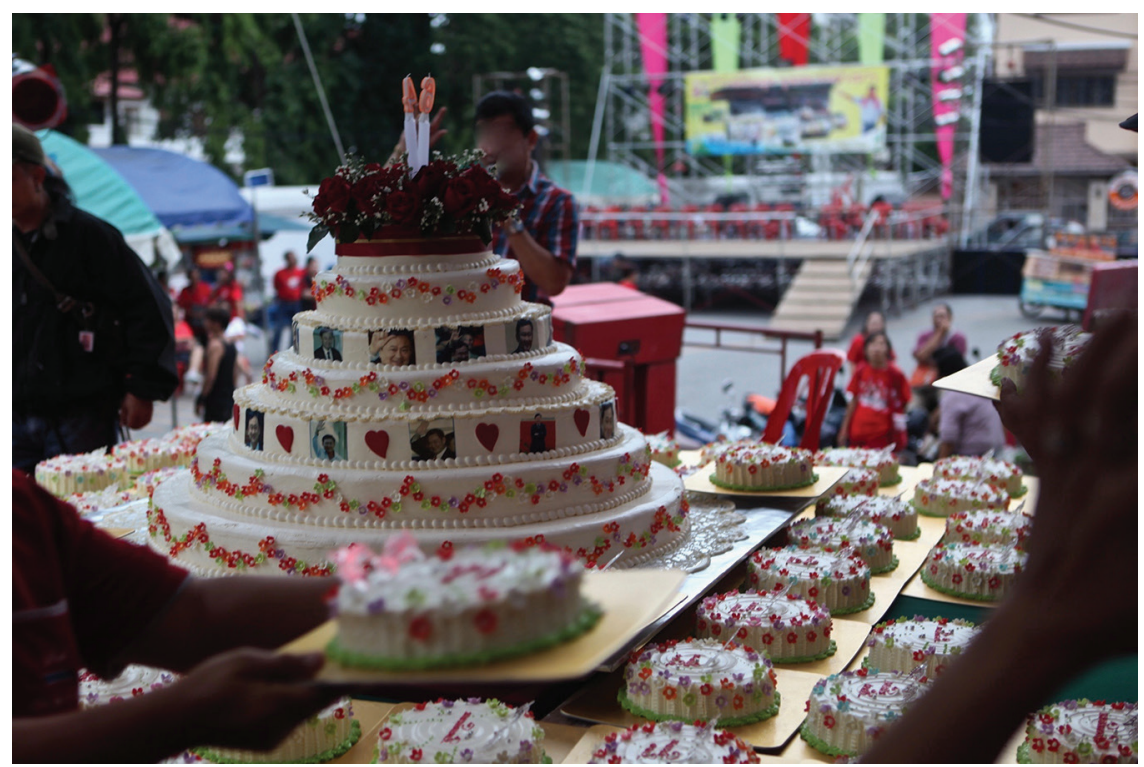

Figure 1. A woman helping to display Thaksin's birthday cake. Photo by Bo Kyeong Seo. 
leader delivered some comments on the meaning of the day: "We are gathered here to celebrate Dr. Thaksin's birthday and wish for the development of Thai people and society." I was later told that the collected money would be donated to build a new radio station for Chiang Mai Red Shirt groups.

After the merit-making ceremony, around fifty boxes of twelve-inch, sugarcoated buttercream cakes and a custom-made cake decorated with Thaksin's face and sugar roses arrived at the hall. A catchy song that started with "Thak, Thak, Thaksin" filled the space with a festive mood, and at around noon, more than a hundred people lined up for free food. Ta was busy distributing khanom jin, silken noodles with a rich, fragrant blood jelly sauce, a food for celebration. She explained to me that, like her, the people who ran the other food stalls had voluntarily prepared food to share their "red hearts" with each other. Another woman joined us in conversation, saying: "It's very sad that Thaksin couldn't work for us anymore. All those ammat (ruling elite) are so jealous of him, because people love him too much. We really want him back home." I spent the afternoon with a group of elderly women listening to their sympathetic comments on Thaksin's extended exile, although speeches by local Pheu Thai politicians on Thaksin's life and legacy periodically interrupted our conversations. ${ }^{8}$

The mood of the party changed entirely in the evening with the playing of ear-blasting music. More than a thousand people, young and old, women and men, clad in red crowded the venue, entertained by troops of dancers and witty satirists. The highlight of the night was a phone call to Thaksin, who was known to be in Hong Kong. At around 9 p.m., local organizers took to the stage and dialed the number. As the ringtone echoed through the speakers, the space felt charged with excitement and high spirits. The first try failed, but on the second attempt, the phone was finally answered, only for the crowd to hear a voice recording saying, "Your call cannot be connected at this time." Wiping away the disappointment, those on stage invited the crowd to sing a happy birthday song together for Thaksin. The mood remained cheerful, but it was getting late for the older women. Ta had already left the venue by the time the stage was covered with a dancing crowd. A man with a microphone sporadically yelled, "Are you ready to fight for equal rights? Fight for democracy? Will you keep fighting?"

This event showcases various modes of participation that give a concrete sense of collectivity and intimacy. The day passed with a lively stream of people coming and going, while a religious ceremony, communal eating, and a celebration 
mixed with rally cries took place in turns. A common thread that ran through the day's activities was "love" (rak), the admiration and pity for Thaksin. This affective force binding those gathered played a significant role in defining these ordinary participants both as "populist followers" and as "anti-coup, democratic supporters" (see also Klima 2006).

On the one hand, this event cannot be entirely freed from the charges of populist deception. Thaksin's celebrity-like status actively came into view through various props, and ideological demagoguery was in evidence. The crowd-pleasing entertainment mixed with propagandistic information on Thaksin's family, as well as the theatrical attempt to make an international phone call to him, exemplify political schemes adopted to sustain and reproduce his paternalistic leadership during his self-imposed exile. As this event exhibits both the voluntary and induced aspects of the Red Shirts' mobilization, ${ }^{9}$ people's emotional attachment to the plutocrat confirms the criticism that they are not proper liberal citizen subjects who embody the democratic ideals of deliberative participation. ${ }^{10}$ In the Bangkokcentered elite view, this staged manifestation of trust and longing for Thaksin proves the conviction that Red Shirt supporters are credulous rural masses lacking sophistication or civil competence.

The 2006 coup was justified on the basis that uneducated and "bribed" rural electorates could not make a "rational" decision about Thaksin's handouts, so that sabotaging affection toward a morally problematic politician became a key strategy of the military and the royalist establishment (Winichakul 2008; Hewison and Kitirianglarp 2010). Daena Aki Funahashi's (2016, 108) ethnography vividly shows how elite bureaucrats working in the health sector pathologize people like Ta, who had guaranteed the electoral victories of the Shinawatras, as having no "'mental immunity' to the cunning of politicians."

On the other hand, this event contains much more complex forces that cannot be subsumed under Thaksin's supposed cunning. The Red Shirts saw Thaksin's return as more than just bringing their favorite politician back to power: they viewed it as recovering democratic rule. For them, Thaksin's ouster unequivocally confirmed that they were not "equal and collectively sovereign citizens" (Ferrara 2015, 250) but, rather, under oligarchic rule. At the time of this event, there was tangible concern that the newly elected Yingluck Shinawatra, Thaksin's sister who had won the 2011 election to become the first woman prime minister of Thailand, could be toppled by another coup. The people gathered that day represented the most powerful electoral majority of the past two decades who had determined to exercise their power at the ballot box. In this context, it seems more than fair to 
describe the Red Shirts as the new political force that has "successfully redrawn Thai political space to make themselves heard" (Charoensin-o-larn 2013, 218).

While such condemnations, expectations, and hopes are mutually invested in the Red Shirts, their public displays, including the event described earlier, reveal that the link between the purportedly populist and the supposedly democratic lies in conflicting shapes of "the people": a social group coming into existence through the ritualized experience of collective effervescence (Durkheim 1995), an emotionally charged crowd seemingly possessing a collective mind and therefore being prone to mob rule (Le Bon 2002), ${ }^{11}$ and the assembling of masses of individuals to make democratic demands and expressions (Juris 2012; see also Mazzarella 2010). While the Red Shirts can be associated with all these modes of collectivity, it seems clearer at this junction that Thaksin plays a certain role not as an actual mover and shaker, but as a potent and sympathetic object. The way this day-long event was organized reveals how the "relations of affective belonging and coexistence" — what Neringa Klumbytė (2011) calls "political intimacy" — are forged with Thaksin. Instead of reinscribing a populist leader's or related political institutions' monopoly on politics, we need to understand how these different modes of collectivity provide circumstances for participants. At stake here is not simply the incompatibility of different modes of popular participation but rather the question of how individuals who once constituted "the people" lived through populist mobilization and what mattered to them.

\section{THE HEARTH ON THE PROTEST SITE}

Born in Korat, one of four cities in the northeastern region of Thailand, Ta moved to Chiang Mai when she was around thirty. As a landless laborer with elementary schooling, she mostly worked selling food. She married twice and raised six daughters and one son. When I first visited her in 2012, she was living in a rented house, a small one-bedroom concrete shack. Ta used to live in a "proper" house with her second daughter, but since turning to the Red Shirts, she had become estranged from some of her children. Ta had to move out from her daughter's house when her grandson, who was working in a subdistrict office as a public servant, felt ashamed of his Red Shirt grandmother and began to quarrel with her.

Ta recounted that she "rose up with the Red Shirts from the beginning," but 2010 proved a life-changing year for her. On March 12 of that year, the United Front for Democracy against Dictatorship (UDD), the largest Red Shirt group, launched a mass protest against the unelected government led by Abhisit Vejjajiva. Along with hundreds of thousands of Red Shirts from the northern and northeast- 
ern regions, Ta departed for Bangkok and joined a protest that would last more than two months, calling for the dissolution of parliament and new general elections. Protesters occupied the heart of Bangkok's business district with encampments and rallies, effectively disrupting the normal rhythms of the city with their immense presence. This time, Red Shirt supporters not only formed the crowd; they lived within it.

Ta immediately found her role in taking care of this new social body of the people: distributing food. She told me,

Some protesters were OK to buy their own food, but there were lots of people who were not affluent enough. Then, there were the guards. They worked really hard and also needed to eat. Who would cook for them? Yellow Shirts accused us of all being paid by Thaksin. Then, where was his money? I didn't get any money from him. I received small donations from people, a sack of rice, a kilo of pork, packs of noodles, and sometimes used my own money. I'm not rich at all, but my heart is rich enough to share. Even soldiers and police got water and food from me.

In support of her daughters and friends in the local market in Chiang Mai, Ta set up her own portable hearth on the street. Her routine as a protester resembled that of a cook: she woke up at 3 a.m., started cooking rice, washed dishes, and prepared food until 1 p.m., before taking a brief rest and packing food for those guarding the barricades. Feeding people eventually became the main reason for her protracted stay in Bangkok.

In Ta's explanation, her commitment to distributing food at the protest sites did not much differ from what she used to do for merit-making in Chiang Mai. She told me, "We can make merit anywhere. It's just the same thing, sharing food in the temple and for the Red Shirts. It's about helping people in need." When she showed me the pictures taken during the 2010 protests, I could see her pouring soup into disposable bowls and handing them to a long line of people. In the photograph, her head was completely shaved. Ta explained to me that this formed her own act of protest. "I want to show that an ordinary woman from Chiang Mai also can shave her long, long hair for a greater cause." She shared with other Red Shirt protesters the political aim to occupy the capital until a date was set for general elections. 


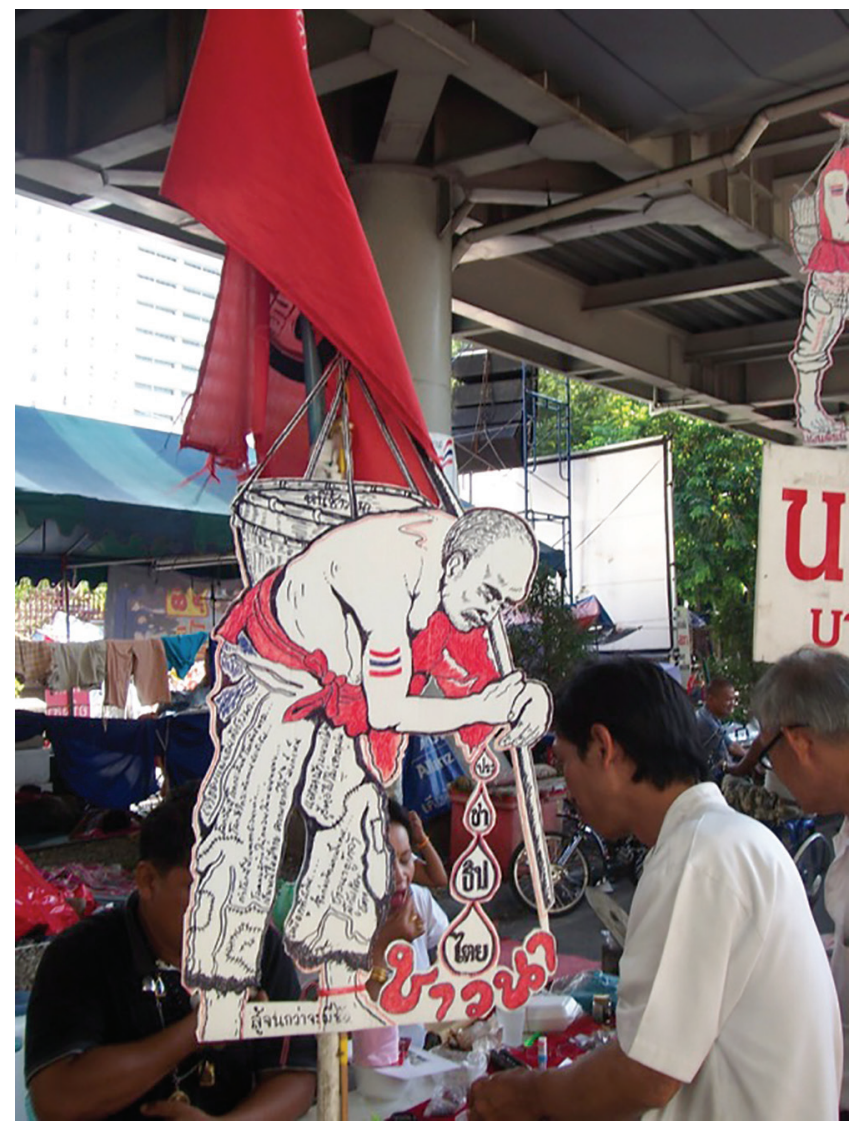

Figure 2. A banner depicting a farmer's burden and quest for democracy. The picture was taken during the 2010 Red Shirt protest. Photo by Bo Kyeong Seo.

The Red Shirts' call for democracy and, more broadly, their desire to choose and change governments were met by severe forms of state violence. On April 10, when a violent clash between protesters and the military at Khok Wua intersection resulted in the loss of life and injuries for both military personnel and civilians, Ta was there too. ${ }^{12}$ Clouds of tear gas filled the streets, bullets were fired, and, with a damp cloth over her mouth, Ta barely managed to escape the scene. She describes it as a terrifying moment, but she did not yet want to return to Chiang Mai. When army units began to launch a full-scale crackdown to disperse protesters on May 14, Ta still remained. She explained, "People started to leave, but I couldn't. What would the rest of the people eat? Water was cut, there was no gas, and nothing much left to eat. In the end, I made a fire with plastic packages and cooked some noodles. Only a bottle of soy sauce was left_- that's all_-but the people still ate 
well." On the final day of the protest, May 19, she took refuge in Wat Pathumwanaram, a small temple hidden between luxurious shopping malls. In the temple, full of injured people, she witnessed another terrifying shooting. ${ }^{13}$ The Red Shirts' protest occupation eventually turned out to be "the most deadly incident of mass violence in modern Thailand" (Haberkorn 2018, 190). As the result of a series of military crackdowns, at least ninety people died and more than two thousand were injured (Human Rights Watch 2011).

The routine of the everyday meal - even on the dawn of a bloody crackdown - paradoxically underlined the graveness of the transgression that Ta experienced. Precious human beings who should be cared for and fed were instead ruthlessly killed. The military justified its attack on civilians by the suspicion that a group of heavily armed protesters was inciting violence. Yet a deeper symbolic structure that denies people like Ta equal status as citizens and human beings really permitted the military operation. During and after the protest, in everyday and institutional discourses, the Red Shirts were compared with "barbarians," "buffalos," ${ }^{4}$ and "germs," ultimately being described as things that lacked the recognizably human capacity of self-determination. ${ }^{15}$ While these metaphors of undifferentiated savagery and contagion reflect the hegemonic power that renders Red Shirts less than human, Ta's care work for her fellow protesters speaks to our equality and shared humanity as vulnerable beings with needs.

When Ta's engagement in protest politics centers on cooking and food distribution, it asks the important question of what populist-democratic demand may emerge from this direct way of giving. By illuminating Sufi Muslim practices of sharing food in the context of the 2011 Egyptian protests, Amira Mittermaier (2014) suggests that such local traditions of hospitality can offer a radical vision for social and political change, as they enable alternative forms of distribution and relationality that center on the attunement to the other's present needs. Predicated on Theravada Buddhist traditions of liang (providing food or eating together), ${ }^{16}$ Ta's gifting of food shares a similar sense of justice that "does not mean that the rich ought to give to the poor but rather proceeds from acknowledging the profound dependency and interdependency of humans" (Mittermaier 2014, 64). The protest site indeed constituted a suitable place for making merit by feeding, as it was where protesters' mutual vulnerability was confirmed and had to be dealt with. Here, feeding the hungry proved meritorious as well as political. Thus, the sense of immediacy that Ta experienced among the protesting crowds as a determined activist points to a direct confirmation of the force of collective commensality. Ta's cooking on the streets formed part of what sustained the collective body of the 
Red Shirts and its unruly force. And this powerful mode of togetherness, as Ta attested, was neither granted nor given by other mediating political institutions, but nurtured by the participants' own efforts.

\section{HOT BLOOD AND DISPIRITED HEART}

The violent attack on the Red Shirts revealed how the state betrayed its nation, by forcefully dividing and destroying it. This traumatic disruption lingered even after the main demands of the 2010 protest had been realized. General elections were eventually held in 2011, and the Pheu Thai Party won a majority of parliamentary seats. While this pro-Thaksin electoral landslide especially in the north and northeastern provinces seemed to signal the Red Shirts' long-awaited victory, Ta felt more loss than gain. The formal investigation into the fatal shootings of civilians had proven slow, and the state's emphasis on "reconciliation" depended on a callous disregard of responsibility. The political milieu had changed, and so Ta's mode of being a Red Shirt also could not remain the same.

In early 2012, Ta was invited by a Red Shirt cable TV channel to talk about the shootings she had witnessed during the 2010 protest. Two years had passed, but her memory was still vivid. "I don't know how they found me," she said, "but I was really glad to have a chance to talk about what happened at that time. I want to tell the truth of what I saw there." In the copy of the video clip that she gave me, her voice was calm, but her eyes were fierce.

Think about who did what. Who shot the people there, and who ordered the shooting? I really want to ask them, all those powerful people like Abhisit and Suthep. We are all the same, humans. We are all Thais. How, then, could they pull a gun on us? Couldn't Abhisit feel shame? Killing so many people to keep his seat? Why didn't he have any compassion for us? How could they walk around freely without any punishment?

The former Prime Minister Abhisit Vejjajiva and his deputy Suthep Thaugsuban had announced the emergency decree and ordered the military crackdown during the 2010 protest. ${ }^{17}$ While these two had been exempted from any punishment, their public presence made Ta's "blood get hot [leuat hawn]." For her and many other Red Shirt supporters, this delayed justice clearly signaled that they were still treated as not only less-than-full citizens but also as less than fully Thai. Ta could not stop pondering how the state could harm its own people without any remorse or repercussions. 
To grasp why her sense of harm and danger did not cease with the change of government, but instead began to haunt her further, it is crucial to understand the connection Ta made between a struggle for equal rights and full national membership marked by the quintessence of Thainess (khwam pen thai). ${ }^{18}$ Their opponents had rendered the Red Shirts "un-Thai" because they deemed their call for equality and justice a challenge to the monarchy, one of the three pillars of Thainess (Ferrara 2015, 250-52). Although Red Shirt supporters had varying views on the monarchy, the Yellow Shirts accused them of wishing to subvert the royal establishment and so becoming an enemy of the Thai nation (Chachavalpongpun 2011). ${ }^{19}$ "If they shoot me, so be it," Ta once told me, admitting that she was afraid that one day some vehement Yellow Shirt supporters would come to her house and attack her. Even in Chiang Mai, she thought that being known as a hard-line Red Shirt in the village could expose her to danger at any time. Ta finally moved to another housing compound whose owner was a locally well-known Red Shirt army official, and where she felt more secure.

Besides the growing sense of anger and insecurity, another significant change occurred in Ta's "Red" heart. Ta found that the Yingluck government failed to deliver on its promise to compensate victims of the military crackdowns. A key incident was when she heard that a barricade guard whom she knew from the 2010 protests had been arrested. The forty-five-year-old man finally returned home after an eleven-month detention in a so-called safe house. His health had seriously deteriorated due to alleged torture, and he died a month after his release. Although his wife, working as a garbage collector, went to Bangkok and made a compensation claim for his death, it had yielded no response. When Ta told me this story, bitterness emerged sharply from her voice:

At his funeral, there was not a single local politician from the Pheu Thai Party or Red Shirt leader. No one was interested in his death. Why didn't they come to help us? .. . I heard that 7 million baht was given to the families of those killed in Bangkok, but where has that money gone? The [Yingluck] government should help people like him who were arrested and lost their lives. And what are the Red politicians and leaders doing now? They should take care of villagers like him. The head of the family died and three children have been left behind. Who will send them to school? People said that the Red Shirts do not abandon each other, but what's happening now? The Red Shirts should fight against the double standards, but now what we 
are doing is also double standards. I am beginning to feel tired of this. I don't know how long I can be with the Red Shirts.

The sense of tiredness and losing strength that Ta expressed is something that only comes after the exertion of a great amount of effort and care. During this unprecedented historical juncture, she actively participated in the political process that eventually changed the government. Yet, for her, it turned out to be an ambivalent victory. The lack of attention to a fellow Red Shirt's tragic death indicates that the objectives of the Red Shirt movement, its campaigns against double standards (song matrathan), and its quest for equality and solidarity are failing to be realized. Here, Ta's use of the phrase double standards seems notable. Originally, the Red Shirts had adopted this term to emphasize the unequal treatment of them and the opposing Yellow Shirts. Given that the Yellow Shirt protesters who blocked Bangkok's airports had not received substantial penalties, the violent repression of the Red Shirts proved judicial bias. While double standards is widely used to indicate larger systems of injustice suppressing the Red Shirts in general, Ta expands this concept to evaluate the movement's internal hierarchy and inequalities.

Ta's hot blood and dispirited heart speak to the multilayered meaning of being a Red Shirt in the aftermath of the 2010 protest. Although the collective body she nurtured was disaggregated, her political life had continued revolving around her memory of togetherness. Ta could not stop talking about, feeling for, and giving meaning to the Red Shirt uprisings. This form of affective enactment, or "corporeal thinking" (Thrift 2004, 67), shows how the political collectivity is reassembled at a time when the populist promise of justice and equality becomes compromised. Ta's lost faith in the potential of the Red Shirt movement is inseparable from her acute sense of the unequal distribution of power and suffering even among her own chosen political community. Yet, at this juncture, the sense of disappointment does not mean that Thaksin and the Red Shirts no longer make for her political intimates. Rather, the very recognition of collective failing has become integral to her populist belonging.

\section{LIFE BETWEEN ASPIRATION AND AFFLICTION}

When I met Ta briefly in 2014 just after the military coup that again had overthrown the democratically elected government, she felt quite sure that the soldiers would not stay for long. She was wrong. They did not leave, and the coupinstalled military government eventually ruled the country for five more years. Under the junta's tight control, activities related to the Red Shirts were severely 
suppressed. Some told me that Red Shirts and Yellow Shirts no longer existed. Some said that it was a time to be patient and wait. When I visited Ta again in early 2016, she told me, "It's all over now." She had aged and looked weaker than she had before.

"You know this village belongs to Thaksin's housing project for poor people?" Ta asked. Her new home was in a suburban neighborhood where every two-story building looked the same. ${ }^{20}$ Modest, timeworn houses were lined up in a row; some of them stood empty. Ta had moved there after her only son's death. "It is still a Red Shirt village," she said. "Only a handful of people are Yellow Shirts." Although she told me that she had entirely disconnected herself from the movement, her world still seemed divided in two. Sitting with me in the little courtyard, she asked how I had been doing. When I inquired about her health, she admitted, "It's been so difficult. Last year, I spent a week in hospital. It's not like I used to be." Ta's major concern at this time was that she was barely making ends meet and had to ask her children for support. She continued, "I worked hard all my life, but now I have nothing." As she continued to talk, she interspersed her concerns about her current hardship with examples of her past activism. "Since I was tear-gassed in my face [during the 2010 Bangkok protests], I can't breathe comfortably. The guy living behind my house, he became disabled after he was severely beaten by soldiers in Bangkok. The people who tried to do something through the Red Shirts, they were poor people. But the people who benefited from the Red Shirts were not the poor."

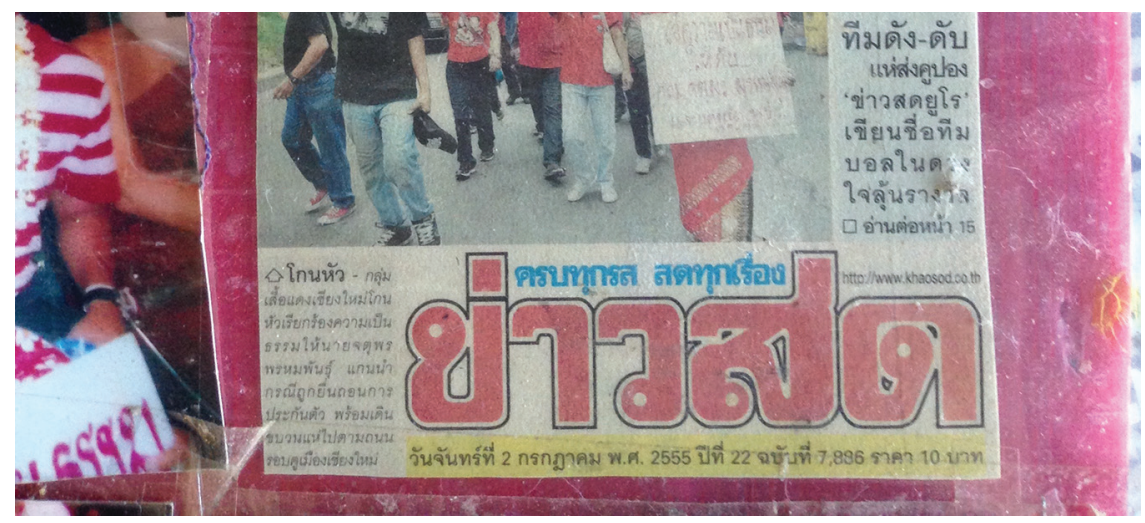

Figure 3. One of Ta's newspaper clippings. Photo by Bo Kyeong Seo.

That day I noticed that the affects surrounding Red Shirt symbols had taken on a different valence. Looking around Ta's new home, I realized that the Red 
Shirt paraphernalia that used to fill her space had all gone. The calendar with Thaksin and Yingluck's picture still hung on the wall, but the several collages she had made with pictures of Red Shirt protest sites and newspaper clippings had disappeared. These collages had served as the symbols of her identity. When I asked when she had thrown them away, she went to find them, bringing them back in a box full of clutter. I asked whether she regretted participating in the Red Shirt movement. She reflected:

It doesn't mean that I don't like Thaksin anymore. He did good things for the poor. I still think that we have a debt to repay him. And I made my own choice, so there was no regret. We did good deeds to help society, to build democracy. But people have begun to forget about this already. We tried very hard, but nothing turned out to be satisfactory. Red Shirt leaders abandoned us in the end, and my life has become harder. Sometimes I feel so angry at myself. No one forced me to do anything. I did. There is no one to blame for what happened to me. Will the Red Shirts rise up in arms again? I don't know. I can fight again, but what about my life? Who can I rely on for that?

In the pictures, crumpled and covered in dust, I could see Ta marching at the head of the line, holding a banner saying "Release Red Shirt Leaders," frying a huge number of fish balls, and making merit with other people all wearing red. Her time spent with and for the Red Shirts was depicted there, but it was cherished no more. She now read these pictures as evidence of defeat.

Her sense of betrayal toward the Red Shirt movement might be interpreted as an unavoidable outcome of the populist movement: the Shinawatras, their political party, and the local UDD leadership opportunistically exploited people's aspirations for justice and change, remaining careless about the sacrifices that those people made. Yet in Ta's narrative, she did not see herself as a victim. Rather, she was struggling to secure her everyday life in the time of demobilization.

Instead of reading Ta's renouncing gesture as a symptom of trauma, I understand it as a form of political affliction. This does not suggest that the historical consequences of this populist mobilization were not violent. It may be that trauma works as a "legitimizing instrument" (Fassin 2017, 16) that secures the moral status of a victim, but her distress and alienation have not been recognized as a valid form of suffering, nor have they been acknowledged or resolved in a larger social and historical context. Instead, her suffering has remained in the background of her daily life. By carefully attending to Delhi's poor neighborhoods, Veena Das 
$(2015,1)$ notes how small forms of violence "are assimilated within the normal and yet not fully absorbed in it," and she reformulates the notion of affliction to unravel a form of suffering that appears as "the corrosion of everyday life" (Das 2015, 2). The ordinary affliction Ta experienced evinces what remains when the vitality of the collective social body ebbs away.

The milieu of threat that permeates Ta's everyday life now takes a different shape to the one it took at the height of the street protests. Since 2014, the junta leader Prayuth Chan-ocha has created a repressive regime that actively adopts the tactics of intimidation and surveillance, ${ }^{21}$ and life in this climate of fear is both normal and corrosive. Ta's contrasting reports on her neighborhood reveal this strange entanglement: she assured me that "things are going on just the same as usual except the economy," while also telling me that "eleven people were arrested in the nearby village because of their connection to the local Red Shirt group." There were no critical events that urgently compelled her to, in her words, "fight back," but at the same time she "didn't know how else to feel but angry at being forgotten.” Rule by guns had replaced populist enchantment: affect had become flattened, feelings seemed less ebullient, and life had lessened. ${ }^{22}$

\section{THE UNFINISHED QUALITY OF POPULIST POLITICS}

I do not focus on Ta's engagement with and detachment from the Red Shirts to confirm the death of this popular movement in Thailand. Rather, I have focused on how this populistic-democratic movement opened a field of multiple becomings. By tracing Ta's various modes of being within the Red Shirt movement, I have shown the temporality of political mobilization that has fluctuated with the untenable hyphen between crowd and citizen, emotion and reason, dependency and emancipation, and aspiration and affliction. The point is not whether the movement has made Ta into a populist or democratic subject. Populism or democracy does not anchor itself to a distinguishable, fixed subject position. Rather, as Ta's layered experiences show, they are spun into existence "through singular and precarious acts" (Rancière 2006, 96), and their unstable coalescence offers fertile ground for the constitution of a new political subjectivity. Ta's journey allows us to appreciate two crucial dimensions relevant to understanding the unfinished quality of populist politics.

First, instead of approaching populist affect as a product or function of socioeconomic and political structures, we should place more emphasis on the generative work that compels political judgments and practices. Such an affect-centered approach helps grasp populist politics not as a manifestation of rooted collective 
identities but as a process of multiple becomings. In the field of Thai studies, several anthropologists have illuminated the changing rural livelihoods and local electoral cultures that fueled the rapid growth of the Red Shirt movement (Kitiarsa 2012; Walker 2012; Keyes 2014; Nishizaki 2014). While Ta’s background — a poor, working-class resident of Chiang Mai coming from rural origins_-evidences similar socioeconomic characteristics to that of the majority of Red Shirt supporters, it is crucial to note that her unsettled courses of participation were not solely determined by the structures of inequality. We should not treat various affective registers that intertwine with Ta's narratives — such as affection, anger, disappointment, ambivalence, and loss — simply as epiphenomena of an underlying structural problem, since they constituted the changing sense of being "the people" and transformed the relations between the self and popular sovereignty. Ta's multiple modes of being - as part of a celebrating and protesting crowd, as a skeptical observer, as a self-sacrificing activist, and as an afflicted person — do not converge into a single identity, but indicate conflicting subject positions engendered through populism.

Second, by focusing on the process of becoming, it is possible to examine how populism involves both joyful and hurtful aspects of political life. The popular fascination with Thaksin and the jouissance of being part of the Red Shirts reveal the vivid presence of an exceptional figure with charisma and a zone of political intimacy created by and through him. ${ }^{23}$ Within this populist enchantment, Ta herself had also become a charismatic figure in the sense that she had set herself as exemplary of the ideal of the Red Shirts: in the protest sites, she shared merit with the crowd by feeding them, sustained the vitality of the collective body of the people, and so amplified the call for justice and equality. While we could understand her fascination with Thaksin and the Red Shirts as an illiberal disposition to immediacy and spectacle, her care work for the vulnerable undeniably indicates a democratic ethos of commitment to sharing (Asad 2011). Yet when the transmitting chain of charismatic authority that had galvanized the populist movement was broken, her energy waned accordingly. Attentiveness to these connections, rifts, and disjunctures helps us grasp populism not as a master concept but as an experience-laden notion substantiated through concrete memories, imaginaries, and temporalities.

Thailand's recent turbulent history of populist mobilization, democratic struggle, and authoritarian returns has wider relevance for complicating our view of the global rise of populism. In her recent book, Chantal Mouffe $(2018,82)$ asserts that populist movements can provide a viable strategy to strengthen equality and social justice, as they contain the potential to radicalize political demands by 
stressing "the demos as an essential dimension of democracy." Instead of speculating about the revolutionary potential of populism per se in Thai politics, I have focused on the complexity of acting and living that brings the demos into existence. The Thai experience points to the changing conceptions and experiences of political life from the unstable, hyphenated, and afflicted position of populist subjects. If a variety of heterogeneous struggles are assembled under populist-democratic demands, grasping this tangled chain of becomings may be the key to confronting the openness of the political, helping us investigate the conflicts and disagreements that keep the category of the demos alive.

\begin{abstract}
In this article, I explore the ways in which political subjectivities take shape through populist mobilization and dissipation. While the rise and increasing electoral success of populist movements across the world are largely attributed to charismatic leadership that conjures the will of "the people," much less known is how people become populist subjects at a particular historical juncture. By attending to personal accounts of participation and detachment in a mass movement known as the Red Shirts in Thailand, I explore how the politics of becoming that emerges from this movement obfuscates the conventional distinction between populist and democratic identification. The articulation of populist subjects' aspiration and affliction provides a window into the undetermined aspects of political mobilization from the realm of the ordinary. [political subjectivity; mass mobilization; affliction; populism; becoming; Red Shirts; Thailand]
\end{abstract}

\title{
บทคัดย่อ
}

ในบทความนี้ ข้าพเจ้ามุ่งศึกษาแนวทางการก่อร่างสร้างอัตวิสัยทางการเมือง ผ่าน การมีส่วนร่วมในการเคลื่อนไหวแบบประชานิยมตลอดจนการสลายตัวของการเค ลื่อนไหวดังกล่าว ในแง่หนึ่ง ความสำเร็จในการเลือกตั้งที่พบได้ในหลายประเทศทั่ว โลก มาจากการเคลื่อนไหวแบบประชานิยม ซึ่งโดยมากมักจะกล่าวถึงผู้นำที่มีเอกลัก ษณ์ มีความสามารถในการชักจูงโน้มน้าว และสามารถตอบสนองต่อความต้องการ ของ "มวลชน" อย่างไรก็ตาม การศึกษาเกี่ยวกับปัจเจกหรือผู้ที่เข้าร่วมการเคลื่อนไห วแบบประชานิยมผ่านห้วงวิกฤตการณ์หรือการเปลี่ยนแปลงทางการเมืองนั้นยังมีน้อย ในการศึกษานี้ ข้าพเจ้าอาศัยเรื่องราวและประสบการณ์ของผู้ที่มีส่วนร่วมในการเคลื่อนไ หวทางการเมืองของกลุ่มคนเสื้อแดงในประเทศไทยจนกระทั่งปลีกตัวออกจากการเคลื่อ นไหวดังกล่าว เพื่อสำรวจการเมืองของการกลายเป็น (Politics of Becoming) ที่เกิดขึ้นภ ายในบริบทการเคลื่อนไหวแบบประชานิยม ทั้งนี้ ข้อค้นพบของข้าพเจ้าทำให้ความเข้าใ จต่อแนวคิดเดิมที่แบ่งแยกขั่วกลุ่มอัตลักษณ์ทางการเมืองแบบประชานิยมออกจากกลุ่ม อัตลักษณ์ทางการเมืองแบบประชาธิปไตยนั้นสับสนยิ่งขึ้น ข้าพเจ้าเสนอให้เราทำความเ ข้าใจกับความสับสนดังกล่าว รวมถึงปฏิเสธการมองว่าความหลากหลาย ไม่เป็นระเบียบ 
ทวิลักษณ์ของความหมาย และมิติทางอารมณ์ความรู้สึกของผู้ที่มีส่วนร่วมในการเคลื่อ นไหวแบบประชานิยมนั้น เป็นปัญหาที่ต้องได้รับการเยียวยาแก้ไข หากแต่ภาวะดังกล่า วเป็นลักษณะสำคัญที่ชี้ให้เห็นว่าประชานิยมมีส่วนในการก่อร่างสร้างอัตวิสัยแบบใหม่ การทำความเข้าใจกับความมุ่งหวัง ความปราถนา และความบอบช้ำของผู้ทีมีส่วนร่วม ในการเคลื่อนไหวดังกล่าว อาจเป็นหนทางที่จะช่วยให้เราทำความเข้าใจกับแง่มุมใหม่ๆ เกี่ยวกับการเคลื่อนไหวทางการเมือง จากปริมณฑลของคนธรรมดาสามัญ [อัตวิสัยทา งการเมือง การเคลื่อนไหวมวลชน ความบอบช้ำ ประชานิยม การกลายเป็น คนเสื้อแดง ประเทศไทย]

\section{국문초록}

본 논문은 포퓰리즘 운동의 확대와 해소 과정에서 정치적 주체성이 만 들어지는 다양한 양상을 탐구한다. 포퓰리즘 정치의 전세계적 성장과 선 거 정치에서 커져가는 영향력은 흔히 대중 혹은 인민의 의지를 결집시킬 수 있는 카리스마적 지도자의 성공과 등치되어 왔다. 그러나 과연 어떻게 대중 혹은 인민이 특정한 역사적 시점에서 포퓰리스트가 되는가에 대해 서는 충분한 논의가 이루어지지 못한 바 있다. 이러한 문제의식을 바탕 으로 본 논문은 태국 레드셔츠 운동의 흥망성쇠를 경유한 한 개인의 삶 경험을 탐색하고, 이를 통해 대중 운동에 기반한 되기(becoming)의 정치 가 포퓰리즘과 민주주의에 대한 관습적 구분을 흐트러트리는 양상에 주 목한다. 포퓰리스트 주체성을 고무하는 복잡한 정동과 의미들은 민주주 의 정치를 저해하는 병폐가 아니며, 역으로 정치적 주체성의 새로운 형 식들이 만들어지고 작동하는 방식을 핵심적으로 보여준다. 포퓰리스트 주체들의 변화에 대한 열망과 수난의 경험은 일상의 영역에서부터 정치 적 동원의 아직 결정되지 않은, 불확정적 속성을 드러낸다. [정치적 주체 성, 대중 운동, 수난, 포퓰리즘, 되기의 정치, 레드셔츠, 태국]

\section{NOTES}

Acknowledgments I am deeply grateful to Aunt Ta and all the interlocutors I met in Chiang Mai for inviting me into their lives. I am also very grateful to Philip Taylor for our many conversations over the years that have significantly contributed to my thinking on populism and subjectivities. For helpful feedback on very early versions of this work, a special thank-you goes to the late Nicholas Tapp, as well as to Andrew Walker, Geoff Buchanan, and Preedee Hongsaton. I would also like to thank Tyrell Haberkorn and Prasert Rangkla for kindly making additional comments and suggestions on a later version of the manuscript. I further owe a debt of gratitude to the three anonymous reviewers, as well as the editors of Cultural Anthropology, who provided crucial comments that helped clarify my argument. This article is much stronger because of the reviewers' thoughtful input, and because of Christopher Nelson's editorial work during the final stage of revision. I am also grateful to Petra Dreiser and Jessica Lockrem for copyediting and proofreading. Preedee Hongsaton and Thirayut Sangangamsakun provided invaluable help in translating the abstract from English to Thai. Any mistakes are my own. The writing of this article was partly supported by the Yonsei University Future-leading Research Initiative (2018-22-0101).

1. While the Red and Yellow Shirts were the two main camps that had created polarization in this period, there were a significant number of people opting for "no color." This 
suggests that political antagonism in Thailand was not simply binary, but rather could be fragmentary.

2. The latest Thai general elections were held in March 2019, and support for the Pheu Thai Party - the successor to Thaksin's original Thai Rak Thai Party - appeared to be stable as before, but not dominating (Selway and Hicken 2019). Pheu Thai won the largest number of seats (136 house seats, 21 more than the pro-junta party Phalang Pracharat), but failed to form a government. This is because the constitution, drafted by the military in 2016, ensures that the 250-seat senate is entirely appointed, and the prime minister does not need to be a sitting member of parliament. For more analysis of the 2019 election result, see Termsak Chalermpalanupap (2019), and for election monitoring, see the interim report by the Asian Network for Free Elections (2019).

3. For example, see Anek Laothamatas (2006) and Pasuk Phongpaichit and Chris Baker (2008, 2009). By focusing on how Thaksin Shinawatra turned out to be a populist by maneuvering various political demands and challenges, Kevin Hewison (2017) draws attention to populism as a form of politics that transcends any individual populist politician.

4. The Red Shirts is made up of heterogeneous groups: long-time followers of Thaksin, a broad social constituency associated with an alliance called the United Front for Democracy against Dictatorship (UDD), and political groups that opposed the military coup although they do not necessarily identify themselves as Thaksin or UDD supporters.

5. Not only royalist politicians and citizens but also the monarchy itself has played a significant role in Thai politics (McCargo 2005; Winichakul 2008). Yet, in this article, I do not include my informants' views on the monarchy so as to avoid any possible repercussions. Thailand's lèse-majesté law, which forbids the defamation and insult of the monarchy, has been increasingly enforced since the 2006 coup to silence political opposition.

6. For more details on the mobilization of the Yellow Shirts, especially in the context of electoral politics, see Kevin Hewison and Kengkij Kitirianglarp (2010) and Prajak Kongkirati (2016).

7. Ta is a pseudonym.

8. In the 2011 election, Pheu Thai, fronted by Thaksin's sister Yingluck Shinawatra as their party head, won a majority of seats in parliament with strong support from the Red Shirts.

9. For a substantive analysis of the leadership and organizational structure of the Red Shirts, see Naruemon Thabchumpon and Duncan McCargo (2011).

10. William Mazzarella $(2015,105)$ perceptively notes this tension in that "in the imagined biography of the liberal subject . . . the crowd represents a childish moment of savage indistinction: corporeal, affective, and irrational."

11. Stressing the irrationality of crowds, Gustave Le Bon $(2002,22)$ famously argued that crowds are "distinguished by feminine characteristic . . . like women, it goes at once to extremes."

12. According to a report by the People's Information Center: The April-May 2010 Crackdowns (2017, 24-28), twenty-seven people were confirmed to have died as a direct result of the military operations implemented on April 10, 2010, and two additional deaths were reported in connection with the demonstration on the same day.

13. For a chronological and first-hand documentation of the 2010 April-May Bangkok Red Shirt protest, see Claudio Sopranzetti (2012). Wat Pathumwanaram had been known as a safe place for protesters to seek shelter, yet military forces eventually opened fire on this spot, leaving six people dead and many more injured. For a full report, see the People's Information Center: The April-May 2010 Crackdowns (2017).

14. In Thai, the buffalo appears in verbal insults as a symbol of idiocy or with sexual connotation. See also Stanley J. Tambiah (1969).

15. Thongchai Winichakul's (2010) vivid description written at the height of the protest captures the sense of horror projected onto Red Shirt protesters.

16. Penny Van Esterik's (1996, 23) classic work on this norm shows how food sharing works not only as a "metaphor for intimacy and closeness" but also as an "arena for negotiating 
and displaying power and hierarchy." While the practice of liang (nurturing) is found in various social contexts including gendered norms of mothering, it goes beyond the realm of femininity and takes a central place in imagining and realizing a productive form of power and protection.

17. The final report from the Truth and Reconciliation Commission of Thailand (TRCT), which was released in September 2012, failed to specify who was responsible for the deaths during the April-May 2010 protests. Both Abhisit Vejjajiva and Suthep Thaugsuban were indicted for their roles in the crackdown, yet the case against them was eventually dismissed in 2014. For more details, see Haberkorn (2018).

18. See also Michael Herzfeld (2016) and Thongchai Winichakul (1994).

19. The political allegiance to the monarchy within the Red Shirt movement has fluctuated, especially after the 2010 protest and the death of King Bhumibol in 2016. For increasing royalism in Thailand, see Thongchai Winichakul (2016), and for the anti-royalist shift within the Red Shirts, see Anonymous (2018).

20. She was living in one of the public housing projects launched by the Thaksin government in 2003.

21. According to Thai Lawyers for Human Rights (2018), in the last four years the regime has summoned more than 800 people for "attitude adjustment" and more than 1,800 cases dealing with civilians have been assigned to military courts.

22. Claudio Sopranzetti (2018) also offers a nuanced account of how motorcycle taxi drivers in Bangkok who had actively participated in the Red Shirt movement experienced a similar affective downturn after the 2014 coup.

23. While the moral aspect of charisma (barami, a form of effortless, pre-given power) has been extensively analyzed in the context of Thai politics and kingship (Kitiarsa 2006; Jackson 2009; Sopranzetti 2018), here I draw on Weber's sense of charisma that can be earned, routinized, and transmitted.

\section{REFERENCES}

Anonymous

2018 “Anti-Royalism in Thailand since 2006: Ideological Shifts and Resistance.” Journal of Contemporary Asia 48, no. 3: 363-94. https://doi.org/10.1080/00472336.2018.1 427021.

Arditi, Benjamín

2004 "Populism as a Spectre of Democracy: A Response to Canovan." Political Studies 52, no. 1: 135-43. https://doi.org/10.1111\%2Fj.1467-9248.2004.00468.x.

Aretxaga, Begoña

2003 "Maddening States." Annual Review of Anthropology 32: 393-410. https://doi. org/10.1146/annurev.anthro.32.061002.093341.

Asad, Talal

2011 "Thinking about the Secular Body, Pain, and Liberal Politics." Cultural Anthropology 26, no. 4: 657-75. https://doi.org/10.1111/j.1548-1360.2011.01118.x.

Asian Network for Free Elections

2019 "International Election Observation Mission (IEOM) to the Kingdom of Thailand's 2019 General Election: Interim Report.” Asian Network for Free Elections, March

26. https://anfrel.org/anfrel-interim-report-on-the-conduct-of-the-2019-thaigeneral-election/.

Bessire, Lucas, and David Bond, eds.

2017 “The Rise of Trumpism." Hot Spots series, Fieldsights, January 18. https://culanth. org/fieldsights/series/the-rise-of-trumpism.

Biehl, João, and Peter Locke, eds.

2017 Unfinished: The Anthropology of Becoming. Durham, N.C.: Duke University Press.

Canovan, Margaret

1982 “Two Strategies for the Study of Populism.” Political Studies 30, no. 4: 544-52. https://doi.org/10.1111/j.1467-9248.1982.tb00559.x. 
Chachavalpongpun, Pavin

2011 "The Necessity of Enemies in Thailand's Troubled Politics." Asian Survey 51, no. 6: 1019-41. http://doi.org/10.1525/as.2011.51.6.1019.

Chakravartty, Paula, and Srirupa Roy

2017 "Mediatized Populisms: Inter-Asian Lineages." International Journal of Communication 11: 4073-92. https://ijoc.org/index.php/ijoc/article/view/6703/2157.

Chalermpalanupap, Termsak

2019 "Thailand's Recent Elections: Disappointments, Surprises and Non-Surprises." Perspective 2019, no 31. https://www.iseas.edu.sg/images/pdf/ISEAS_ Perspective_2019_31.pdf.

Charoensin-o-larn, Chairat

2013 “Redrawing Thai Political Space: The Red Shirt Movement.” In Cleavage, Connection and Conflict in Rural, Urban and Contemporary Asia, edited by Tim Bunnell, D. Comaroff, Jean Parthasarathy, and Eric C. Thompson, 201-21. Dordrecht, Netherlands: Springer.

2011 "Populism and Late Liberalism: A Special Affinity?" Annals of the American Academy of Political and Social Science 637, no. 1: 99-111. https://doi.org/ 10.1177\%2F0002716211406079.

Das, Veena

2015 Affliction: Health, Disease, Poverty. New York: Fordham University Press.

Durkheim, Emile

1995 The Elementary Forms of Religious Life. Translated by Karen E. Fields. New York: Free Press. Originally published in 1912.

Fassin, Didier

2017 “The Endurance of Critique." Anthropological Theory 17, no. 1: 4-29. https://doi. org/10.1177\%2F1463499616688157.

Ferrara, Federico

2015 The Political Development of Modern Thailand. Cambridge: Cambridge University Press.

Funahashi, Daena Aki

2016 "Rule by Good People: Health Governance and the Violence of Moral Authority in Thailand.” Cultural Anthropology 31, no. 1: 107-30. https://doi.org/10.14506/ ca31.1.06.

Haberkorn, Tyrell

2018 In Plain Sight: Impunity and Human Rights in Thailand. Madison, Wisc.: University of Wisconsin Press.

Herzfeld, Michael

2016 Siege of the Spirits: Community and Polity in Bangkok. Chicago: University of Chicago Press.

Hewison, Kevin

2017 "Reluctant Populists: Learning Populism in Thailand." International Political Science Review 38, no. 4: 426-40. https://doi.org/10.1177\%2F0192512117692801.

Hewison, Kevin, and Kengkij Kitirianglarp

2010 “Thai-Style Democracy': The Royalist Struggle for Thailand's Politics.” In Saying the Unsayable: Monarchy and Democracy in Thailand, edited by Søren Ivarsson and Lotte Isager, 179-202. Copenhagen: NIAS.

Holland, Dorothy, and Jean Lave, eds.

2001 History in Person: Enduring Struggles, Contentious Practice, Intimate Identities. Santa Fe: School of American Research Press.

Human Rights Watch

2011 "Descent into Chaos: Thailand's 2010 Red Shirt Protest and the Government Crackdown." New York: Human Rights Watch.

Jackson, Peter A.

2009 "Markets, Media, and Magic: Thailand's Monarch as a 'Virtual Deity." Inter-Asia Cultural Studies 10, no. 3: 361-80. https://doi.org/10.1080/14649370902949366. 
Juris, Jeffrey $\mathrm{S}$.

2012 "Reflections on \#Occupy Everywhere: Social Media, Public Space, and Emerging Logics of Aggregation." American Ethnologist 39, no. 2: 259-79. https://doi. org/10.1111/j.1548-1425.2012.01362.x.

Kanchoochat, Veerayooth, and Kevin Hewison

2016 "Introduction: Understanding Thailand's Politics." Journal of Contemporary Asia 46, Keyes, Charles no. 3: 371-87. https://doi.org/10.1080/00472336.2016.1173305.

2014 Finding Their Voice: Northeastern Villagers and the Thai State. Chiang Mai: Silkworm. Kitiarsa, Pattana

2006 "In Defense of Thai-Style Democracy." Asia Research Institute, National University of Singapore, October 12.

2012 "From Red to Red: An Auto-Ethnography of Economic and Political Transitions in a Northeastern Thai Village." In Bangkok May 2010: Perspectives on a Divided Thailand, edited by Michael J. Montesano, Pavin Chachavalpongpun, and Aekapol Chongvilaivan, 230-47. Chiang Mai: Silkworm.

Klima, Alan

2006 “Thai Love Thai: Financing Emotion in Post-Crash Thailand." Ethnos 69, no. 4: 445-64. https://doi.org/10.1080/0014184042000302335.

Klumbytè, Neringa

2011 "Political Intimacy: Power, Laughter, and Coexistence in Late Soviet Lithuania." East European Politics and Societies 25, no. 4: 658-77. https://doi. org/10.1177\%2F0888325410387638.

Kongkirati, Prajak

2016 "Thailand's Failed 2014 Election: The Anti-Election Movement, Violence and Democratic Breakdown.” Journal of Contemporary Asia 46, no. 3: 467-85. https:// doi.org/10.1080/00472336.2016.1166259.

Laclau, Ernesto

2005 On Populist Reason. London: Verso.

Laothamatas, Anek

2006 Thaksina-prachaniyom [Thaksin-Style Populism]. Bangkok: Matichon.

Le Bon, Gustave

2002 The Crowd: A Study of the Popular Mind. New York: Penguin Books. Originally published in 1895

Mazzarella, William

2010 "The Myth of the Multitude, or, Who's Afraid of the Crowd?" Critical Inquiry 36, no. 4: 697-727. https://doi.org/10.1086/655209.

2015 “Totalitarian Tears: Does the Crowd Really Mean It?” Cultural Anthropology 30, no. 1: 91-112. https://doi.org/10.14506/ca30.1.06.

McCargo, Duncan

2005 "Network Monarchy and Legitimacy Crises in Thailand." Pacific Review 18, no. 4: 499-519. https://doi.org/10.1080/09512740500338937.

Mittermaier, Amira

2014 "Bread, Freedom, Social Justice: The Egyptian Uprising and a Sufi Khidma." Cultural Anthropology 29, no. 1: 54-79. https://doi.org/10.14506/ca29.1.05.

Moffitt, Benjamin

2016 The Global Rise of Populism: Performance, Political Style, and Representation. Stanford,

Mouffe, Chantal Calif.: Stanford University Press.

2018 For a Left Populism. London: Verso.

Nishizaki, Yoshinori

2014 "Peasants and the Redshirt Movement in Thailand: Some Dissenting Voices." Journal of Peasant Studies 41, no. 1: 1-28. https://doi.org/10.1080/030661 50.2013.873409. 
People's Information Center: The April-May 2010 Crackdowns

2017 Truth for Justice: A Fact-Finding Report on the April-May 2010 Crackdowns in Thailand. Bangkok: PIC.

Phongpaichit, Pasuk, and Chris Baker

2008 “Thaksin's Populism.” Journal of Contemporary Asia 38, no. 1: 62-83. https://doi. org/10.1080/00472330701651960.

2009 Thaksin. Chiang Mai: Silkworm.

Rancière, Jacques

2006 Hatred of Democracy. Translated by Steve Corcoran. New York: Verso.

Samet, Robert

2013 "The Photographer's Body: Populism, Polarization, and the Uses of Victimhood in Venezuela." American Ethnologist 40, no. 3: 525-39. https://doi.org/10.1111/ amet.12037.

Selway, Joel, and Allen Hicken

2019 "The Fate of Pheu Thai in the 2019 Elections." Thai Data Points, April 5. https:// www.thaidatapoints.com/post/the-fate-of-pheu-thai-in-the-2019-elections.

Sopranzetti, Claudio

2012 Red Journeys: Inside the Thai Red-Shirt Movement. Chiang Mai: Silkworm.

2018 Owners of the Map: Motorcycle Taxi Drivers, Mobility, and Politics in Bangkok. Oakland: University of California Press.

Tambiah, Stanley J.

1969 “Animals are Good to Think and Good to Prohibit." Ethnology 8, no. 4: 423-59. http://doi.org/10.2307/3772910.

Thabchumpon, Naruemon, and Duncan McCargo

2011 "Urbanized Villagers in the 2010 Thai Redshirt Protests." Asian Survey 51, no. 6: 993-1018. http://doi.org/10.1525/as.2011.51.6.993.

Thai Lawyers for Human Rights

2018 Collapsed Rule of Law: The Consequences of Four Years under the National Council for Peace and Order for Human Rights and Thai Society. Bangkok: Thai Lawyers for Human Rights.

Thrift, Nigel

2004 "Intensities of Feeling: Towards a Spatial Politics of Affect." Geografiska Annaler 86, no. 1: 57-78. https://doi.org/10.1111/j.0435-3684.2004.00154.x.

Van Esterik, Penny

1996 "Nurturance and Reciprocity in Thai Studies." In State Power and Culture in Thailand, edited by E. Paul Durrenberger, 22-46. New Haven: Yale Southeast Asia Studies.

Walker, Andrew

2012 Thailand's Political Peasants: Power in the Modern Rural Economy. Madison, Wisc.: University of Wisconsin Press.

Winichakul, Thongchai

1994 Siam Mapped: A History of the Geo-Body of a Nation. Honolulu: University of Hawaii Press.

2008 “Toppling Democracy." Journal of Contemporary Asia 38, no. 1: 11-37. https://doi. org/10.1080/00472330701651937.

2010 “The 'Germs': The Reds' Infection of the Thai Political Body.” New Mandala, May 3. http://asiapacific.anu.edu.au/newmandala/2010/05/03/thongchai-winichakulon-the-red-germs.

2016 Thailand's Hyper-Royalism: Its Past Success and Present Predicament. Trends in Southeast Asia no. 7. Singapore: ISEAS. 